59 巻 559 号 $(1993-3)$

\title{
ガスエンジン・コージェネレーション・システムの動特性分析*
}

\author{
伊 東 弘 一*1, 横 山 良 平*1 \\ 斯波敬*1, 林秀 和*2
}

\section{Analysis of Dynamic Characteristics of a Gas Engine Cogeneration System}

\author{
Koichi ITO, Ryohei YOKOYAMA, \\ Takashi SHIBA and Hidekazu HAYASHI
}

\begin{abstract}
Dynamic characteristics of a gas engine cogeneration system are analyzed using a simulation model. DYNAMO (dynamic model) is adopted as a simulation language because it enables an easy and flexible change of model structure and parameters. Dynamic characteristics of each piece of constituent equipment are expressed by using dead time and first-order lag elements. Their parameters are determined so that the simulation results match the measured ones accurately enough. The simulation model of the whole system is created by linking each submodel of constituent equipment. The simulation and measurement results show that the proposed modelling method is a useful tool. As an example of dynamic simulations, it is investigated how the location of measurement points influences the temperature of jacket water for cooling the gas engine.
\end{abstract}

Key Words: Systems Engineering, Simulation, Transient Response, Cogeneration, Systems Dynamics, DYNAMO

\section{1.}

コージェネレーション・システム (CGS) は, 電気と 熱のエネルギー供給を同時に行う多入力・多出力シス テムである，電気供給に関しては，周波数および電圧 を十分精度よく制御しながら，需給関係を瞬時に調整 しなければならない。一方，熱供給に関しては，一般 に需給間のある程度の差異は容認されるが, 熱移動の 遅れと熱輸送によるむだ時間などの時間的履歴を考虑 しながら需給関係を満たさねばならない。このように， CGSは電気と熱という基本的に性質の異なるエネルギー 供給を行う必要上, システム全体を適切に運用・制御 していくことは比較的難しい課題となっている。 システム全体の制御問題を考える場合，その基礎と してシステム全体の動特性シミュレーション・モデル を構築し，システムの動的挙動を把握しなければなら ない。しかしながら，個別機器やサブシステムに対し てはシミュレーション・モデルを構築して分析がなさ れた例があるが(1),(2)，システム全体についての分析はな されていない。また、筆者らはシステム全体の設計計

*原稿受付 平成 4 年 8 月 3 日.

*1 正員, 大阪府立大学工学部 ( 3593 堺市学園町 1-1).

*2 大阪ガス (株) ( 0550 大阪市西区千代崎 3-2-95).
画問題や運用計画問題を中心に検討してきたが(3)，機器 の静特性のみを考虑するに留まっており，システムの 動的な挙動に関する知見がほとんど得られていないの が現状である.

システムの動的挙動は計測点，制御方策，および配 管長などに依存し，システムごとに検討する必要があ る、したがって、システム構成や制御方策の各種代替 案について，システムの動的挙動を分析しながら合理 的な案を容易に選択できるようなシミュレーション・ モデルの構筑が必要不可欠である。本研究では, シ ミュレーション言語としてシステム構成や制御方策な どの容易な変更を可能にするDYNAMO(4)を採用し, 実シ ステムに対するシミュレーション・モデルの構築を行 う.さらに, 構築したモデルを利用して, 計測点や配 管長がシステムの動的挙動に与える影䈏について分析 し，本手法の有効性を示す。

\section{主啚町易}

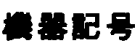

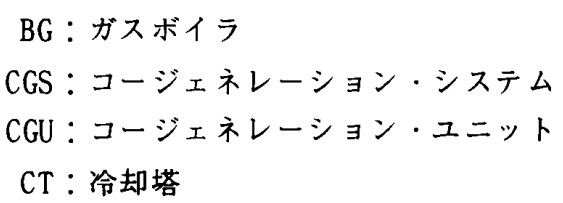


GE : ガスエンジン

$G:$ 発電機

HEX : 温水熱交換器

MV : 三方并

PP : 定流量ポンプ

\section{敦洞器祀号}

FM：流量計

TM：温度計

\section{目町号}

$A$ ：熱交換係数 $\quad \mathrm{kW} /{ }^{\circ} \mathrm{C}$

$a$ : 係数 $\mathrm{kW} /\left(\mathrm{m}^{3} / \mathrm{h}\right)$

$c:$ 比熱 $\mathrm{kJ} /\left(\mathrm{kg} \cdot{ }^{\circ} \mathrm{C}\right)$

$F$ : 都市ガス消費量 $\mathrm{m}^{3} / \mathrm{h}$

$K:$ ゲイン

$P$ : 軸動力 $\mathrm{kW}$

$Q:$ 熱流量 $\quad \mathrm{kW}$

$\bar{Q}^{\mathrm{d}}:$ 熱需要変動量 $\quad \mathrm{kW}$

$T$ : 時定数 $\mathrm{S}$

$t:$ 時間変数 $\mathrm{s}$

$V$ : 配管容量 $\mathrm{m}^{3}$

W: 体積流量 $\mathrm{m}^{3} / \mathrm{s}$

$Z_{\mathrm{P}}:$ 行過き量 ${ }^{\circ} \mathrm{C}$

$\theta:$ 温度 ${ }^{\circ} \mathrm{C}$

$\rho:$ 密度 $\mathrm{kg} / \mathrm{m}^{3}$

$\tau:$ むだ時間 $\mathrm{s}$

添字

$\mathrm{atm} ：$ 室内（温度）

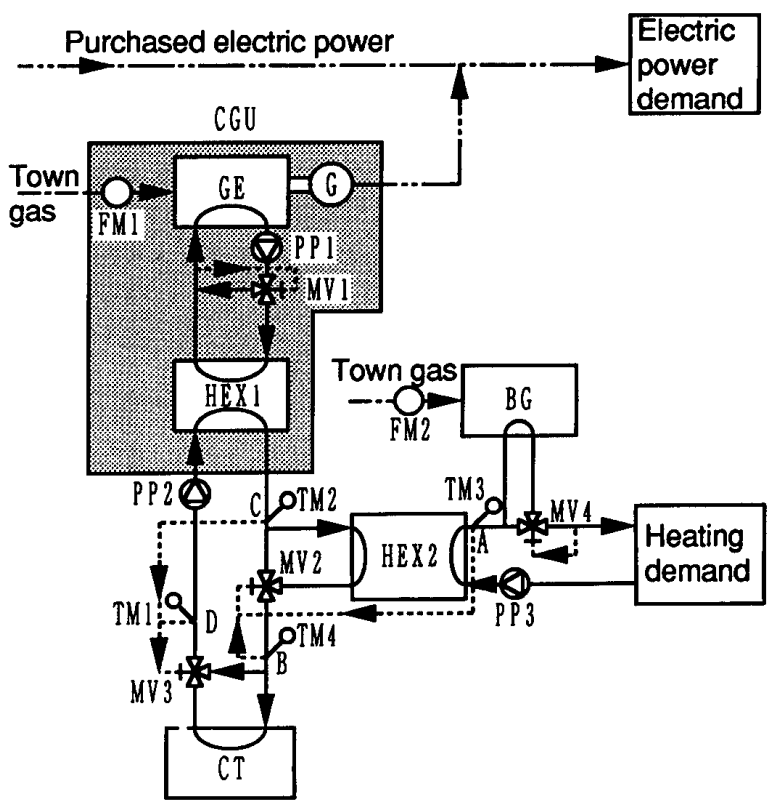

図1対象システム

$$
\begin{gathered}
\mathrm{d}: \text { 需要 } \\
\mathrm{f}: \text { 定格値 } \\
\mathrm{h}: \text { 高温側 } \\
\text { in }: \text { 流入 } \\
\mathrm{l}: \text { 低温側 } \\
\text { out }: \text { 流出 }
\end{gathered}
$$

\section{2. 封争システム}

図1に本研究の対象とした実在のガスエンジンCGSを 示す. 図中, 実線は温水, 一点鎖線は然料の都市ガス， 二点鎖線は電力，破線は情報の流れをそれそれれ示す。 本CGSは, システムの中核となるコージェネレーショ ン・ユニット (CGU)とガスボイラ $(\mathrm{BG})$, 冷却塔 $(\mathrm{CT})$, 熱交換器 (HEX)，ポンプ(PP)，三方弁(MV)，およびそ れらを継ぐ配管などから構成されている。システム内 のCGUは, ガスエンジン発電機 (GE-G), 熱交換器 (HEX1), 三方弁 (MV1)，およびポンプ(PP1)から構成されている. 電力需要は買電およびガスエンジン発電機により供給 される。熱需要は，ガスエンジン $(\mathrm{GE})$ から回収された 排熱，およびガスボイラからの出力により供給される. また，排熱回収量が熱需要量に対して過剩となる場合 には，過剩分が冷却塔によって廃亲される．以上の機 器の他に, 実システムでは冷凍機が設置されている. しかし，本研究では冬期の冷房需要が存在しない場合 にのみ動的挙動を実計測する機会を得たので，対象シ ステムから冷凍機を除外した。

$$
\text { 3. シミュレーション・モデルの策 }
$$

3.1 シミュレーション・モデル ここでは, 四 1 の対象システムに対するシミュレーション・モデル を定常的なパラメトリック・モデルとして構築する。 モデル構築の際には，システムを機器単体に分割し， 基本的には機器単体を一つの集中定数系と見なして, その入出力関係を一次遅れとむだ時間要素で表現する， システム全体のモデルは，むだ時間を考虑した配管と 三方并により各構成機器を接続して棬築される，以下 のモデル化では，各機器の機器記号を省略して表現す る.

（1） ガスエンジン ガスエンジンのモデルを図 2 に示す。都市ガス消费量 $F$ による発生熟量 $Q_{\text {in }}$ は， むだ時間 $\tau$ と係数aにより次式で表すことができる。

$$
Q_{\text {in }}(t)=a F(t-\tau)
$$

また，温水により搬送される熱量 $Q_{\text {out }}$ は，水の比熱を $c$, 密度を $\rho$, 体積流量をW，流入温度を $\theta_{\mathrm{in}}$, 流出 温度を $\theta_{\text {out }}$ とすると次式で表される。

$$
Q_{\text {out }}(t)=c \rho \mathbb{W}\left\{\theta_{\text {out }}(t)-\theta_{\text {in }}(t)\right\}
$$


このとき,ガスエンジン内の温水の代表温度 $\theta$ に関す る微分方程式は, 時定数を $T$ ，ゲインを $K_{1}$ ；室内温 度を $\theta_{\text {atm }}$ とすると次式となる。

$$
T \frac{\mathrm{d} \theta(t)}{\mathrm{d} t}+\theta(t)=K_{1}\left\{Q_{\text {in }}(t)-Q_{\text {out }}(t)\right\}+\theta_{\text {atm }}
$$

また，ガスエンジンの軸動力 $P$ は，ゲインを $K_{2}$ とする と次式で表現される。

$$
P(t)=K_{2} F(t) \text {. }
$$

以上からガスエンジンのモデルをDYNAMO特有のフロー 図で表現すると図3のようになる，図中, Reservoir： 蕃積量などの状態量, Conveyer：むだ時間要素,

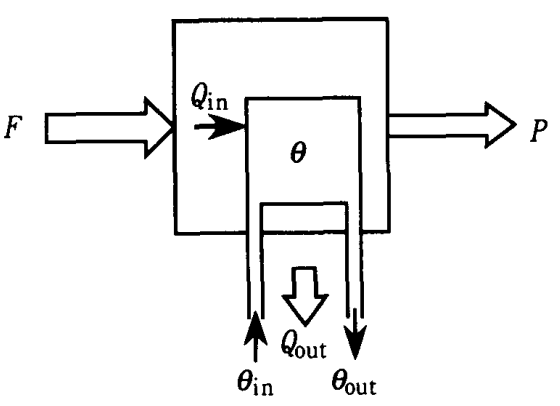

図 2 ガスエンジン・モデル

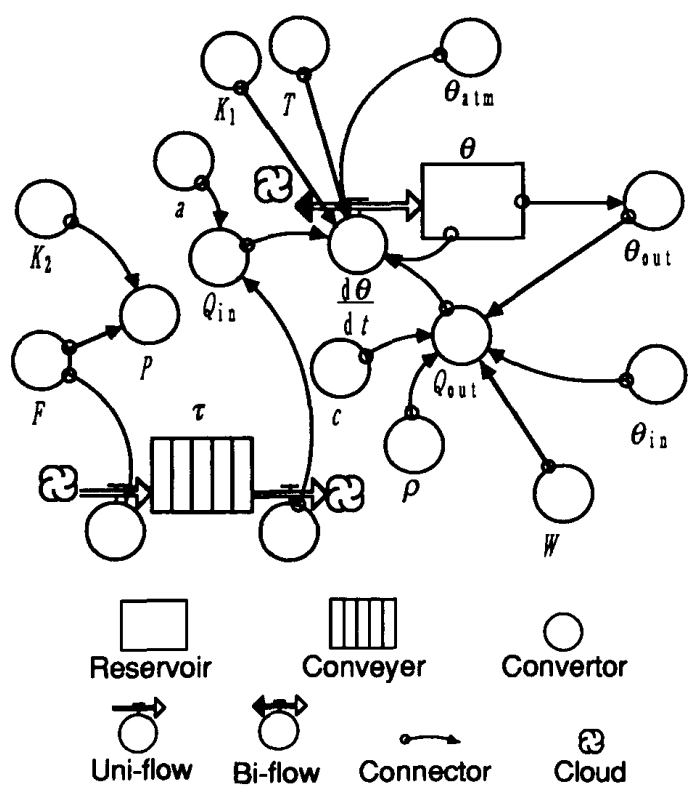

図 3 DYNAMOによるガスエンジンのフロー図

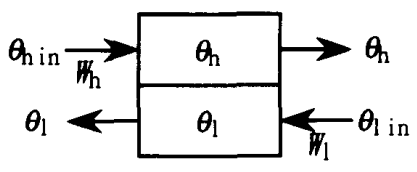

図 4 温水熱交換器モデル
Converter : 関数, Uni-f low : 状態量の変化量 (一方向), Bi-flow: 状態量の変化量 (双方向), Connector: 情報 の流れ，Cloud：無限にある蓄積量をそれぞれ示す.

（2）発電機発電機の発電量はその軸動力で決 められる。ただし，起動時には電圧が確立されてから 遮断機が投入されて負荷運転が開始される.したがっ て，遮断機が投入されて負荷運転が行われているとき は1，そうでないときは 00 値をとる係数らを導入し て発電量 $E$ を次式で表す。

$E(t)=\zeta K P(t)$

ここでは, ガスエンジンを始動してから負荷運転が開 始されるまでの時間を $t_{0}$ として，ガスエンジンが始動 してから $t_{0}$ 秒後に $\zeta=1$ とし, それまでおよび停止指 令を受けた場合には $\zeta=0$ とする.

（3）温水熱交換器温水熱交換器のモデルを図 4 に示す。図中， $\theta_{\mathrm{h}}, \theta_{1}$ はそれぞれ高温側，低温側の 代表温度， $\theta_{\mathrm{h}}$ in， $\theta_{1}$ in はそれぞれの入口温度， $W_{\mathrm{h}}, W_{1}$ はそれぞれの体積流量である，図4は，高温側および 低温側それぞれの流体の温度が均一と考えてモデル化 したものである(5),(6). まず，高温側について考えると， 高温側への入力熱量 $Q_{\mathrm{h}}$ in $(t)$ と温度 $\theta_{\mathrm{h}}(t)$ の関係は次式と なる.

$$
T_{\mathrm{h}} \frac{\mathrm{d} \theta_{\mathrm{h}}(t)}{\mathrm{d} t}+\theta_{\mathrm{h}}(t)-\theta_{\mathrm{atm}}=K_{\mathrm{h}} Q_{\mathrm{h} \text { in }}(t)
$$

ここで，入力熱量は低温側の交換熱量と温水により持 ち込まれた熱量との和となり，次式で表現できる。

$$
\begin{aligned}
Q_{\mathrm{h} \text { in }}(t) & \left.=c \rho W_{\mathrm{h}}(t) \mid \theta_{\mathrm{h}} \text { in }(t)-\theta_{\mathrm{h}}(t)\right\} \\
& +A\left\{\theta_{\mathrm{l}}(t)-\theta_{\mathrm{h}}(t)\right\} \ldots \ldots \ldots \ldots . .
\end{aligned}
$$

同様にして，低温側は次式となる。

$$
\begin{aligned}
& T_{1} \frac{\mathrm{d} \theta_{1}(t)}{\mathrm{dt}}+\theta_{1}(t)-\theta_{\mathrm{atm}}=K_{1} Q_{1} \text { in }(t) \\
& \text { ここで, } \\
& \left.Q_{1 \text { in }(t)}=c \rho W_{1}(t) \theta_{1} \text { in }(t)-\theta_{1}(t)\right\} \\
& +A\left\{\theta_{\mathrm{h}}(t)-\theta_{1}(t)\right\} \ldots \ldots \ldots \ldots
\end{aligned}
$$
また,

$$
A=K_{\mathrm{A}} \frac{W_{1}(t)}{W_{\text {lf }}} \frac{W_{\mathrm{h}}(t)}{W_{\mathrm{hf}}}
$$

（4） ポンプ システム内のポンプはすべて定流 量ポンプである．CGU内のポンプは，ガスエンジンに対 する始動指令の後に運転が開始される.

（5） 三方弁 三方弁の分岐点あるいは合流点に おける流量および温度は弁開度によって決められる。 また，合流する場合，西流体は均一に混合するものと する。弁開度は計測温度と設定温度との偏差に基づき PID制御される。弁開度指示値が制御器から与えられる と, 弁開度はその指示值に向って等速で変化する. 
（6）配管 配管入口温度 $\theta_{\text {in }}$ と出口温度 $\theta_{\text {out }} の$ 関係は，むだ時間 $\tau$ を考慮して次式で表現する。

$$
\theta_{\text {out }}(t)=\theta_{\text {in }}(t-\tau)
$$

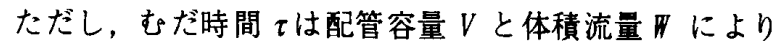
次式で表現される.

$$
\tau=V / W
$$

（7）ガスボイラ ガスボイラは, 保有水温度に よりオン・オフ制御されている。都市ガス消費量によ る発生熱量および水により持ち去られる熱量は, それ ぞれ式(1)，(2)と同様に表される。また，ガスボイラ

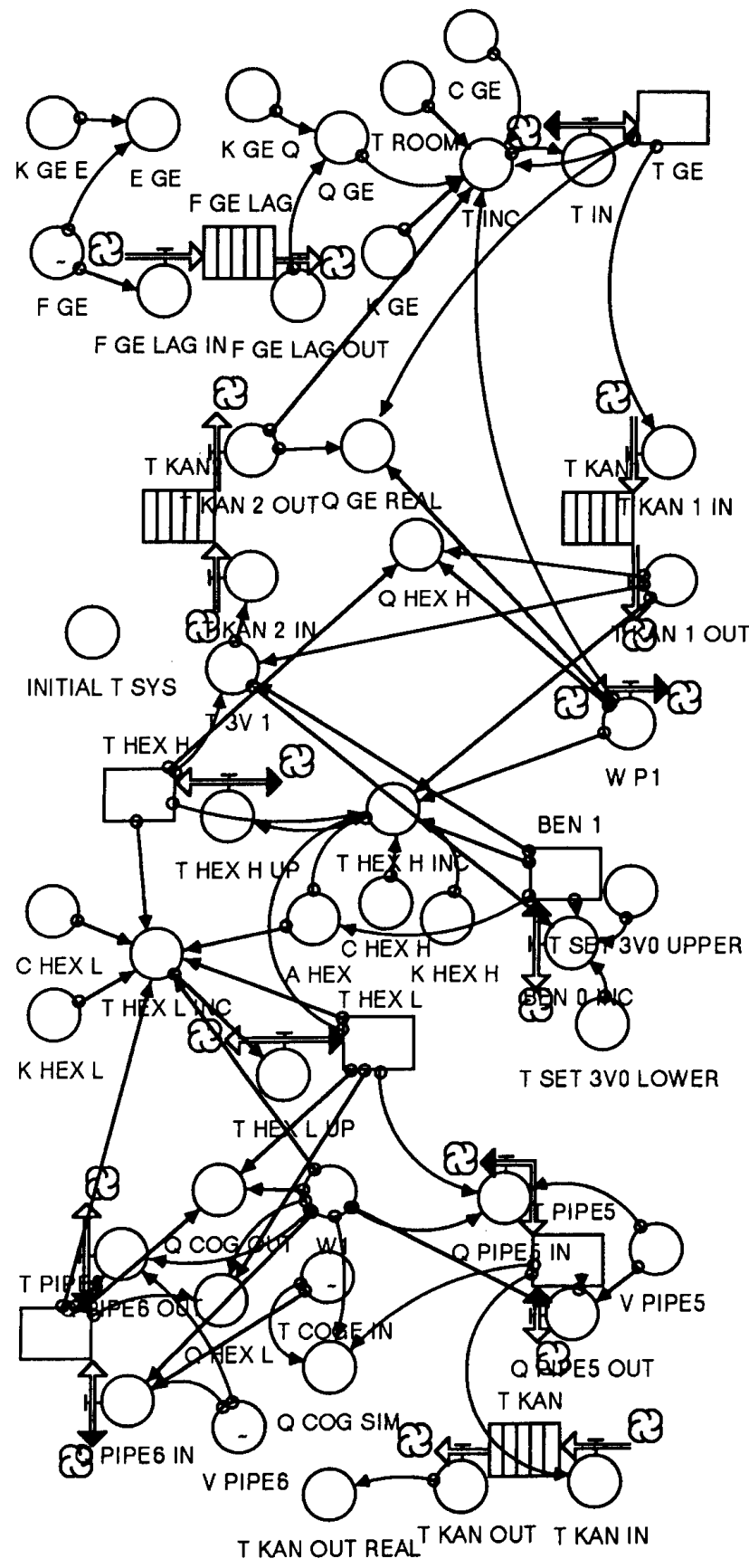

図 5 DYNAMOによるCGUのフロー図
を集中定数系として考えると，ガスボイラ保有水代表 温度 $\theta$ に関する微分方程式は，式(3)と同様に表すこと ができる。

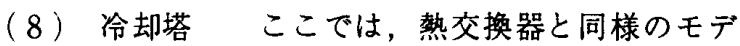
ルにより，冷却塔をモデル化する。

以上から，図 3 のように各機器に対するフロー図を 作成してそれらを接続することにより，システム全体 のシミュレーション・モデルが構築される. 図 $5 に$ DYNAMOによるCGUのフロー図を示す，楆築されたシミュ レーション・モデルは一次の微分方程式系であり，数 值解法としてオイラー法(7)を採用して，シミュレーショ ンを行う.

3.2特性パラメータの決定図1の対象シス テムに対するシミュレーション・モデルの動特性パラ メータを決定するため，温度計および流量計を設置し て，10秒間隔で計測を行った。モデルの各種動特性パ ラメータについては, シミュレーション結果が実計測 データと可能な限り一致するように決定した。一例と して, ガスエンジン発電機の起動時における過渡応答 を取り上げる。実システムにおける実計測データの都 市ガス消費量, 温水の流量および流入温度を与条件と してシミュレーションを行い, 得られた結果と対応す る実計測データを比較検討した。図 6 にCGUの排熱回収 温水出力温度に関するシミュレーション結果および実 計測データを示す. 図 6 より，t=300〜400秒において 温水温度が立ち上がる部分でわずかに差異が見られる ものの再者は十分一致していることがわかる. 以上の ような検討を各構成機器について行うことにより，構 成機器の動特性パラメー夕を決定する。

\section{4.シミュレーション・モデルによる的特性分析}

DYNAMOに基づいて構築された本シミュレーション . モデルは，システム構成や制御方策などの変更が容易 であるので，その特長を生かして種々の動特性分析が 行える。ここでは，その一例として三方弁制御のため

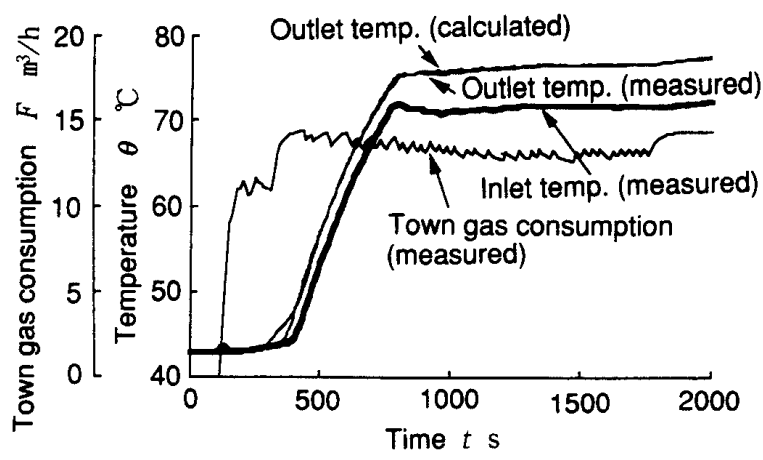

図 6 CGUの過渡応答 
の温度計測点がシステムの動的挙動に及ほす影響につ いて分析する。

従来，図1のシステム内の三方弁MV2およびMV3は， それぞれ計測点BおよびDにおける温度により制御され ている。しかしながら，それ以外にも例えばAおよびC といった計測点による制御が考えられる。そこで，計 測点が以下の温水の温度変動に対してどのような影簐 があるかを分析する。

（1）供給側温水温度

(2) 返り温水温度

表 1 に計測点の組合せに関する検討ケースを，表 2 に各点の設定温度を示す

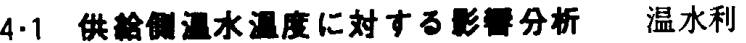
用の観点から制御性能を考えるとき，供給側温水温度 の精度が評価の指標として挙げられる。ここでは供給 側温水温度として図 1 のA点およびC点の温度を取り上 げ，その過渡応答について調べる，具体的には図 7 の ように，一定量のガスエンジン都市ガス消費量 $F$ ，およ びステップ状の変動量 $\bar{Q}^{d}$ を持つ熱需要量 $Q^{d}$ をえて 以下検討する.

表 1 の計測点に対する各検討ケースにおけるA点およ

表 1 温度計測点

\begin{tabular}{|c|c|c|}
\hline Case Valve & MV2 & MV3 \\
\hline $\mathrm{AC}$ & $\mathrm{A}$ & $\mathrm{C}$ \\
\hline $\mathrm{AD}$ & $\mathrm{A}$ & $\mathrm{D}$ \\
\hline $\mathrm{BC}$ & $\mathrm{B}$ & $\mathrm{C}$ \\
\hline $\mathrm{BD}$ & $\mathrm{B}$ & $\mathrm{D}$ \\
\hline
\end{tabular}

表 2 各点の設定温度

\begin{tabular}{|c|c|c|c|c|}
\hline Measurement point & A & B & C & D \\
\hline Set point ${ }^{\circ} \mathrm{C}$ & 74 & 74 & 82 & 74 \\
\hline
\end{tabular}

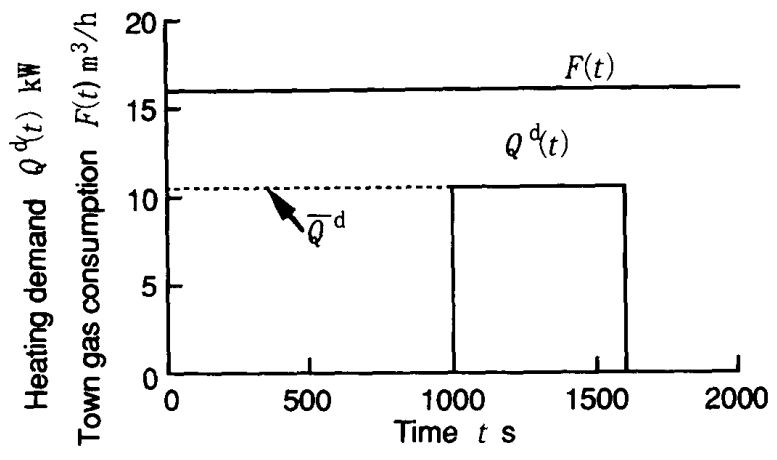

図 7 入力デー夕
びC点の温度変化をそれぞれ図8（a)抢よび(b)に示す。 図 8 (a)によれば, $t=0 \sim 1000$ 秒の熟需要量が零である 時間帯ではいずれの検討ケースもA点の温度と設定温度 との差が大きいが， $t=1000 \sim 1600$ 秒の熱需要量が零で ない時間帯にはA点によって制御を行えばA点の設定温 度に収束していることがわかる．図 $8(\mathrm{~b})$ は，C点で制 御すればC点の温度と設定温度との差が明らかに小さい ことを示している，以上の結果から，供給側温水温度 の精度という点においてはA点およびC点で制御する方 が望ましいということがわかる。

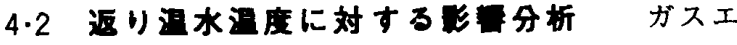
ンジンの保誏という観点から制御性能を考えるとき， 返り温水温度の安定性が重要となる。特に返り温水温 度が設定温度から急激に上昇することはガスエンジン にとって望ましくないことである.そこで，ここでは 制御性能の評価指標としてD点における温水温度が設定 温度から增加したときの行過ぎ量|Zdを取り上げる．返

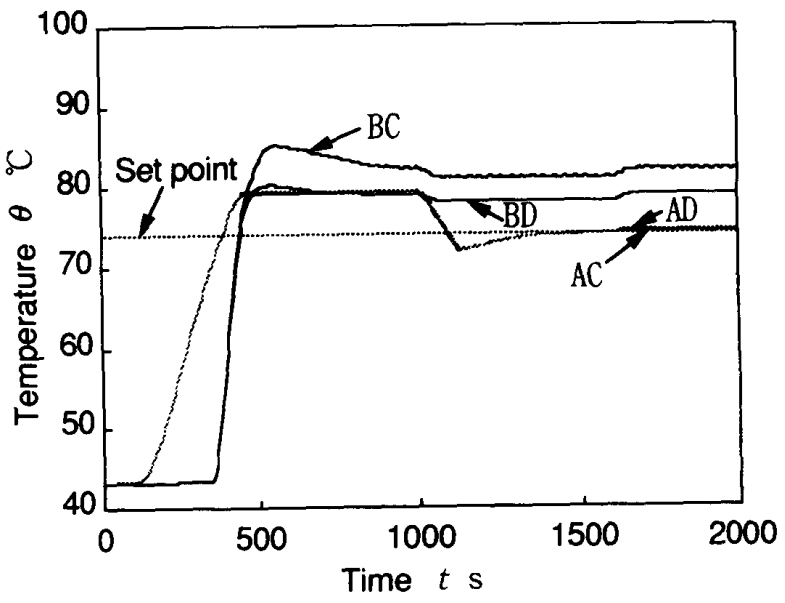

(a) A点

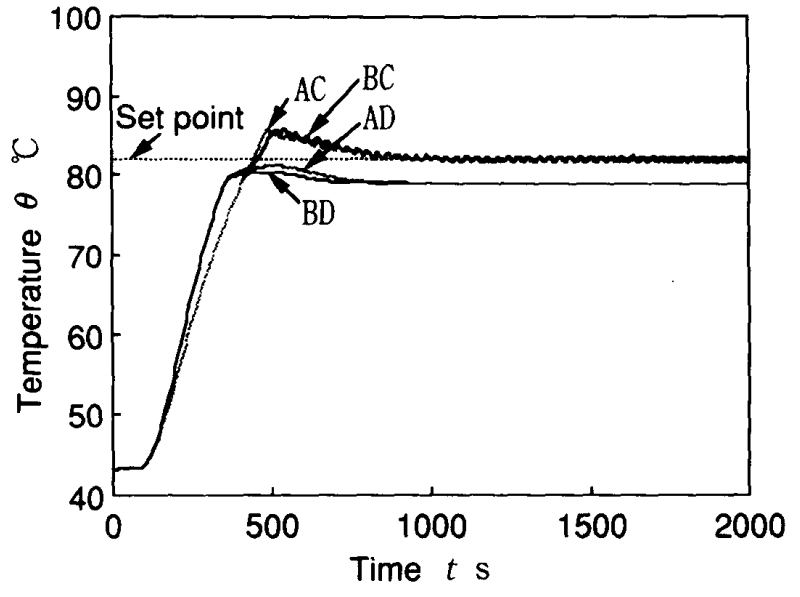

(b) C点

図 8 温度の時間的変化 
り温水温度が急激に上昇する外的要因として, 熱需要 量の急隇を考え，表1の各検討ケースについて調べる. 特に次の二つの量を変化させて分析する。

（1）熱需要変動量の大きさ

(2) CGS内の各構成機器間の配管長

4.2.1 熱需要変動量による影響分析 ここでは, 図 7 のステップ状の変動量 $\bar{Q}^{\mathrm{d}}$ を10.5から63.0まで $10.5 \mathrm{~kW} こ ゙ と に$ 変化させ,この熱需要変動量が計測点に 関する各検討ケースの評価指標に与える影俥を分析す る.CT〜CGU間，CGU〜HEX2間，HEX2〜CT間それぞれの 配管長は等しいものとする.すなわち，配管長を間接 的に表現する温水輸送によるむだ時間を，すべて $3 \mathrm{~s}$ として検討した。

図 9 に熱需要量急滅時の行過ぎ量|Z力引示す。図 9 よ り, 熱需要変動量の隇少に伴い, 行過き量も隇少する ことがわかる，ただし，検討ケース $\mathrm{AC} ， \mathrm{BC} と \mathrm{AD} ， \mathrm{BD}$ で状況が異なる。すなわち，

（1）ケース $\mathrm{AC}, \mathrm{BC}$ ケ場合 グラフは原点より上方 を通り, 熱需要変動量が雾に近づいても，行過ぎ量が 雾に取束しない。

（2）ケース $\mathrm{AD}, \mathrm{BD}$ 場合 グラフはほほ原点を通 る直線で表現でき, 熱需要変動量が零に近づくと, 行 過ぎ量が零に近づく.

以上, 返り温水温度の安定性という点においてはD点 制御の方がC点制御よりも望ましいことが判明した。こ の原因は，C点制御はD点制御に比へ，三方弁と制御用 温度計間で温水輸送によるむだ時間が発生し, それが 制御情報の遅れとなるためであると考えられる。

4-2.2 配管長による影㥽分析 4·2・1項における 分析結果に対する考察に従い, 配管長がC点制御とD点 制御に対してどのように影謷するかを検討する。ここ では配管長を温水輸送によるむだ時間として間接的に

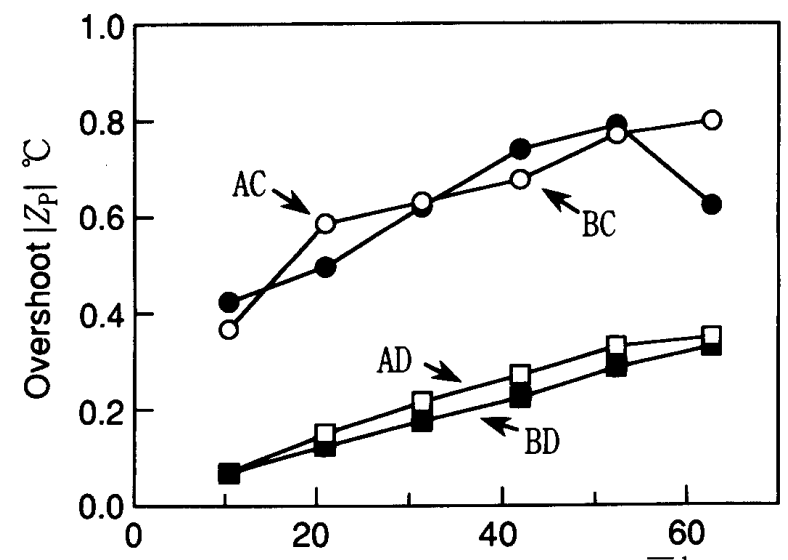

Stepwize variation of heating demand $\bar{Q}^{\mathrm{d}} \mathrm{kW}$

図 9 行過ぎ量（熱需要変動量による影響）
表現しこのむだ時間をパラメータとしてその影帮を 分析する。

各配管のむだ時間に関する検討ケースを表 3 のよう に設定する。また，図 7 における熱需要変動量 $\bar{Q}^{\mathrm{d}}$ を $63 \mathrm{~kW}$ とした。図 10 に熱需要量急隇時の配管長によ

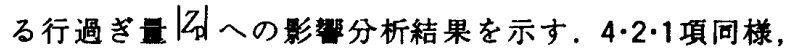
2 通りにわけて考察する。

（1）ケースAC，BCの場合 CGU〜CT間の配管による 温水輸送むた時間 $\tau_{1}$ を短くすることにより，行過ぎ量 を低く抑えることが可能となることがわかる。これは， フィードバック制御を行う場合, 制御用温度計を制御 点に可能な限り近づける方が良いということを意味し ている。

（2）ケース $\mathrm{AD}$, BDの場合 配管長による影翌は全 くない，行過ぎ量の低減のためには，応答の速い制御 用温度計を設置するか，または開閉が速い三方弁を使 用する必要がある。

以上の結果から，C点制御は供給側の温度設定という 観点からは望ましい制御方法ではあるが，その一方で ガスエンジンの保護という観点からはC点制御よりも D 点制御の方が望ましいという結果が得られた。現状の

表 3 配管のむだ時間

\begin{tabular}{|c|c|c|c|c|}
\hline \multirow{2}{*}{ Case } & \multicolumn{5}{|c|}{ Dead time $\mathrm{s}$} \\
\cline { 2 - 5 } & $\begin{array}{c}\mathrm{CT} \sim \mathrm{CGU} \\
\tau_{1}\end{array}$ & $\begin{array}{c}\mathrm{CGU} \sim \mathrm{HEX} 2 \\
\tau_{2}\end{array}$ & $\begin{array}{c}\mathrm{HEX} 2 \sim \mathrm{CT} \\
\tau_{3}\end{array}$ & $\begin{array}{c}\text { Total } \\
\tau_{1}+\tau_{2}+\tau_{3}\end{array}$ \\
\hline I & 2 & 14 & 14 & 30 \\
\hline II & 4 & 13 & 13 & 30 \\
\hline III & 6 & 12 & 12 & 30 \\
\hline IV & 8 & 11 & 11 & 30 \\
\hline
\end{tabular}

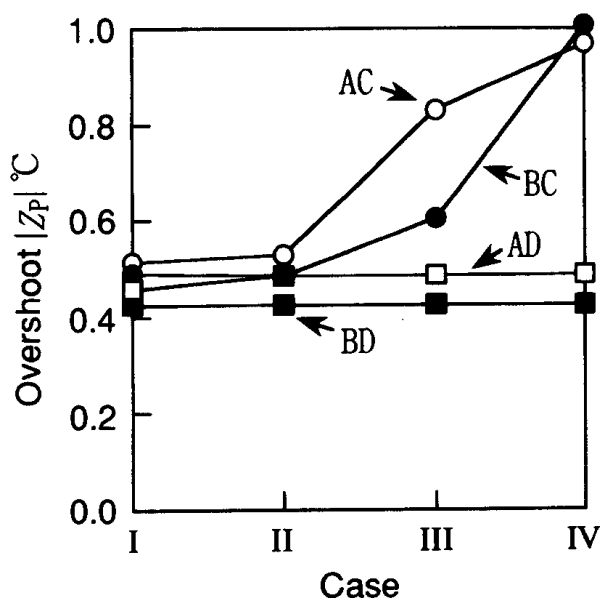

図 10 行過ぎ量（配管長による影翼） 
制衘方法ではガスエンジンの保誏ということを重視し た上でD点制御が行われているといえる.

\section{5.}

本論文では，ガスエンジンを主機とするCGSの動特性 シミュレーション・モデルを構築した。モモ゙ル棈築に おいては，その一般性を十分考虑した上で，シミュ レーション言語としてシステム構成や制御方策の各種 代替案の容易な検討を可能にするDYNAMOを適用した。 さらに，実計測データに基づいて構築したモデルによ り種々の分析を行い，以下の主要結果が得られた。

1) DYNAMOを適用することによって，ガスエンジン CGSの動特性シミュレーション・モデルを柔軟か つ容易に構築でき，代替案検討に対する有効性 についても確認できた。

2) 実計測データと比較することにより，一次遅れ とむだ時間で基本的に実システムの動特性を表 現した本シミュレーション・モデルの有効性が 確認できた。

3) システムの動特性を分析することにより，各種 制御方策の有用性を比較検討することができた。

なお，本研究では，動特性分析の一例として計湘点 の位置が返り温水温度および供給㑡温水温度に対して 与える影望を分析したが, 構築したモデルはそれ以外 にも適用可能である，例えば，運用段階の問嘎に対し ては, 熱・電力需要パターンがそれぞれ変化した場合
のシステム挙動分析などが考えられる，また，設計段 階の問題に対してはモデルの動特性パラメータを変化 させることにより構成機器の適切な種類や規模などを 検討するといったことも可能である.

本研究の遂行にあたり，ご協力いただいた大阪ガス （株）東野耿二氏および川崎重工業（株）田村閏司氏 に，深甚の感謝の意を表します。

\section{文部}

(1) Thompson, H. A. and Fleming, P. J., Parallel Implementations of Gas Turbine Simulations Using Transputers, Proc. Inst. Mech. Eng., Part I, 205-I3(1991), 199.

(2) Jericha, H., Perl, T., and Perz, E., Contribution to the Dynamic Simulation of Thermal Power Plants, Proc. 1991 ASME COGEN-TURBO, (1991), 263.

（3）伊東・横山、コージェネレーションの最䔔計画, (1990), 25 , 産業図曹。

(4) 鈴木, ディシタル・シミュレーション（2），システムと 制御, 17-10 (1973)，614。

（5）增淵，熱交換器の動特性。機誌，62-491(1959)， 1723.

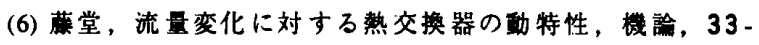
252(1967), 1215.

（7）州之内，数値計算，(1986)，27，サイエンス社。 